\title{
Efisiensi Panel Surya Kapasitas 100 Wp Akibat Pengaruh Suhu Dan Kecepatan Angin
}

\author{
Dahliyah"; Samsurizal $^{2}$; Nurmiati Pasra ${ }^{3}$ \\ 1,2,3 Teknik Elektro, Institut Teknologi PLN \\ ${ }^{2}$ samsurizal@itpln.ac.id
}

\begin{abstract}
Solar radiation has a great effect on the output of the photovoltaic system. Wind speed is directly related to the cooling of the PV system and can also affect the performance of the solar collector. This research looks at the influence of temperature and wind on the efficiency of solar panels. From the results of the tests and calculations, it was found that the temperature of the single crystal panel measured on that day was $44^{\circ} \mathrm{C}$, and the temperature of the polycrystalline panel was $43^{\circ} \mathrm{C}$. The effect of wind speed on the efficiency of the solar module, calculated based on calculations using the linear regression method, shows a correlation level of $R=0.0281$. This means that only about $2.81 \%$ wind speed will affect it. Has solar module efficiency. From the various aspects of the calculations carried out, we can see that the efficiency of the single crystal panel is $11.716 \%$, while the efficiency of the polycrystalline panel is $10.02 \%$. From the calculation results, we can conclude that the efficiency of the single crystal module is significantly increased.
\end{abstract}

Keywords: Efficiency, Solar Panels, Temperature, Wind

\begin{abstract}
ABSTRAK
Radiasi matahari memiliki efek yang besar pada output dari sistem fotovoltaik. Kecepatan angin berhubungan langsung dengan pendinginan sistem PV dan juga dapat mempengaruhi kinerja kolektor surya. Penelitian kali ini melihat sejauh mana pengaruh suhu dan angin terhadap efisiensi panel surya. Dari hasil pengujian serta perhitungan didapatkan sampel suhu panel kristal tunggal yang diukur pada hari itu adalah $44^{\circ} \mathrm{C}$, dan suhu panel polikristalin adalah $43^{\circ} \mathrm{C}$. Pengaruh kecepatan angin terhadap efisiensi modul surya, dihitung berdasarkan perhitungan dengan metode regresi linier, menunjukkan tingkat korelasi $R=0,0281$. Artinya hanya sekitar 2,81\% kecepatan angin yang akan mempengaruhinya. Memiliki efisiensi modul surya. Dari berbagai aspek perhitungan yang dilakukan, kita dapat melihat bahwa efisiensi panel kristal tunggal adalah 11,716\%, sedangkan efisiensi panel polikristalin adalah 10,02\%. Dari hasil perhitungan, kita dapat menyimpulkan bahwa efisiensi modul kristal tunggal meningkat secara signifikan.
\end{abstract}

Kata Kunci: Efisiensi, Panel Surya, Suhu, Angin 


\section{PENDAHULUAN}

Indonesia adalah negara tropis dengan banyak sinar matahari. Seharusnya digunakan jika memiliki potensi yang bagus, salah satunya dengan pembangkit listrik tenaga surya (PLTS). PLTS adalah merupakan salah satu pembangkit yang mengubah energi surya menjadi energi listrik. Pembangkit ini merupakan jenis pembangkit yang ramah lingkungan. Karena bahan bakar fosil semakin menipis dari waktu ke waktu, ada kebutuhan untuk mengembangkan pembangkit listrik tenaga surya ini sebagai sumber energi alternatif.

Letak Indonesia yang berada pada garis khatulistiwa ini diperkirakan mempunyai penyinaran radiasi matahari sebesar $4,8 \mathrm{kWh} / \mathrm{m}^{2} /$ hari. Panel surya mengkonversi energi foton menjadi energi listrik dimana matahari sangat berperan penting dalam hal ini, kondisi lingkungan yang terus berubah bisa mempengaruhi daya output pada panel surya. (Asrori \& Yudianto, 2019). Penyinaran matahari mempunyai dampak yang besar pada keluaran daya sistemphotovoltaic, kenaikan suhu serta cuaca yang berubah - ubah pada panel surya sangat sensitif terhadap kinerja panel surya. Kecepatan angin berhubungan langsung dengan pendinginan system PV yang dapat mempengaruhi kinerja dari panel surya, saat kecepatan angin lebih besar maka akan mendinginkan permukaan luar panel. (Kayani, 2019)

Kecepatan angin di sekitar lokasi panel surya sangat mempengaruhi efisiensi panel surya, hal ini bisa membantu menjaga suhu kaca pada sel surya tetap rendah sehingga suhu kerja pada sel surya tetap optimal. Daya output yang dihasilkan pada panel surya tidak hanya dipengaruhi oleh intensitas radiasi matahari saja, akan tetapi juga dipengaruhi oleh cuaca, seperti kecepatan angin, suhu serta kelembaban. Apabila suhu pada panel naik melebihi suhu standarnya maka akan menimbulkan turunnya daya yang dihasilkan, dikarenakan efisiensi panel nya juga menurun. (PS, Faizal, Widianto, \& Iman, 2018). Berubahnya suhu pada sel surya disebabkan oleh kondisi temperaturnya itu sendiri seperti pengaruh dari kecepatan angin, serta lingkungan tempat panel surya diletakkan.

Panel surya yang rentan terpengaruh dengan perubahan keadaan lingkungan sekitar menyebabkan produksi listrik yang dihasilkan pun bisa berubah, karena saat suhu naik maka bisa menurunkan nilai tegangan yang dihasilkan pada panel surya. Telah banyak penelitian yang telah dilakukan dengan menggunakan parameter - parameter yang mempengaruhi efisiensi pada panel surya seperti pengaruh sudut kemiringan, efek bayangan dll. Akan tetapi parameter seperti hubungan antara suhu dan kecepatan angin belum banyak dilakukan bagaimana pengaruhnya pada efisiensi panel surya. Dari latar belakang diatas, penulis ingin mengkaji sejauh mana pengaruh suhu dan kecepatan angin terhadap efisiensi panel surya. Panel surya yang digunakan pada penelitian ini yaitu panel tipe polikristalin dan monokristalin yang mempunyai kapasitas masing - masing sebesar $100 \mathrm{Wp}$.

\section{METODE}

Metode yang digunakan pada penelitian ini meliputi observasi dan studi literatur. Penelitian ini dilakukan dengan observasi / pengamatan secara langsung di Laboratorium PLTS IT-PLN. Penelitian ini dilakukan selama 6 hari. Penelitian dimulai pukul $09.00-14.00$ WIB dengan pengambilan data setiap 30 menit sekali. Pada tahapan studi literatur ini, peneliti mengumpulkan teori sebagai bahan referensi penelitian. Parameter yang digunakan pada penelitian ini adalah irradiasi matahari, suhu panel surya, suhu ambient (suhu lingkungan sekitar), tegangan, arus, kelembaman serta kecepatan angin. Setelah 
semua data diperoleh, kemudian data tersebut dianalisis menggunakan Microsoft excel dengan menggunakan metode regresi linear untuk mengetahui seberapa besar error / pengaruhnya antara suhu dan kecepatan angin pada efisiensi kinerja panel surya.

Ada beberapa faktor yang menyebabkan kinerja PLTS menjadi kurang maksimal, seperti pengaruh sudut kemiringan, bayangan, tingkat kebersihan panel dll. Namun di penelitian ini pembahasannya difokuskan pada pengaruh suhu dan kecepatan angin saja, berikut adalah pembahasannya. Suhu merupakan salah satu faktor yang mempengaruhi kinerja modul surya. Panel surya terdiri dari beberapa susunan sel surya, yang mempunyai sifat penyerap energi matahari yang sangat baik. Saat panel surya beroperasi dibawah sinar matahari maka terjadi peningkatan suhu pada sel surya. (Khwee, 2013). Saat suhunya semakin naik maka akan berpengaruh juga terhadap daya yang dihasilkan serta akan terjadi pula penurunan pada suatu panel surya. Kecepatan angin juga bisa mempengaruhi kinerja modul surya, hal ini karena meskipun tidak berhubungan langsung dengan intensitas matahari, namun kecepatan angin ini bisa meningkatkan kemampuan system. Saat angin berhembus dengan kencang maka bisa mendinginkan permukaan luar panel. (Kayani, 2019)

Adapun alat yang digunakan pada penelitian ini yaitu panel monokristalin dan polikristalin masing - masing berkapasitas $100 \mathrm{wp}$. Baterai VRLA, solar power meter, solar charger controller, anemometer, digital infrared thermometer dan multimeter digital. Adapun beberapa persamaan yang digunakan pada perhitungan penelitian seperti berikut.

\section{- Rumus Daya Terhadap Suhu:}

$\mathrm{F} p \mathrm{p}=P$ pvstc $x$ F pv $x$ F temp $x \frac{I T}{I T . S T C}$

Keterangan:

P pvstc $=$ kapasitas daya panel saat kondisi uji baku (kw)

$F p v=$ faktor susut $(\%)$

STC $=$

standar test condition ( saat suhu ruang 25 derajat, dan radiasi $1000 \mathrm{w} / \mathrm{m}^{2}$

\section{- Rumus Daya Input:}

$\operatorname{Pin}=\operatorname{Ir} x A$

Keterangan:

Pin = daya input (watt)

Ir $\quad=$ intensitas irradiasi matahari $\left(\mathrm{W} / \mathrm{m}^{2}\right)$

A $\quad=$ Luas area modul surya $\left(\mathrm{m}^{2}\right)$

\section{- Rumus Fill faktor (faktor pengsisian)}

Fill factor adalah salah satu besaran yang menjadi parameter unjuk kerja sel surya, fill faktor merupakan salah satu besaran tak berdimensi yang menyatakan antara 
perbandingan daya maksimum yang dihasilkan sel surya terhadap perkalian antara Voc dan Isc.

$\mathrm{FF}=\frac{V p m \times I p m}{\operatorname{Voc} \times I s c}$

Keterangan:

$\mathrm{Vpm}$ = tegangan pada titik kerja maksimum

$\mathrm{Ipm}=$ arus pada titik kerja maksimum

Voc = tegangan rangkaian terbuka (open circuit)

Isc $=$ arus hubung singkat (short circuit)

Pada saat nilai tahanan variabel mempunyai nilai tak hingga / open circuit maka nilai arusnya akan bernilai minimum (nol), namun tegangannya bernilai maksimum. Tegangan ini disebut dengan tegangan hubung terbuka / open circuit (Voc). Namun, saat nilai tahanan variabel bernilai nol, maka arusnya akan bernilai maksimum dan tegangannya. Peristiwa ini disebut dengan arus hubung singkat / short circuit (ISC). (Napitupulu, 2017). Dapat disimpulkan bahwa semakin besar harga FF (fill faktor) sel surya, maka unjuk kerja sel surya tersebut baik, dan akan mempunyai koefisien konversi energi yang semakin baik pula.

\section{- Rumus Daya Output}

Pout $=$ Vrata - rata $x$ Irata - rata $x F F$

Keterangan:

Pout = daya keluaran (Watt)

Vrata-rata = tegangan sel surya (volt)

Irata-rata = arus sel surya (Ampere)

\section{- Rumus Daya Maksimum}

$\operatorname{Pin}=\operatorname{Ir} \max x A$

Keterangan:

$\mathrm{P}$ in $\quad=$ Daya Input Maksimum (watt)

Ir $\max \quad=$ Nilai Irradiasi Maksimum $\left(\mathrm{W} / \mathrm{m}^{2}\right)$

A $\quad=$ Luasan Panel $\left(\mathrm{m}^{2}\right)$

\section{- Rumus Efisiensi}

$$
\eta=\frac{V \times I \times F F}{\operatorname{Ir} \times A} \times 100 \%
$$

Keterangan:

$\eta=$ efisiensi sel surya $(\%)$

$\mathrm{V}=$ tegangan (volt) 
$\mathrm{I}=$ Arus $($ Ampere0

$\mathrm{FF}=$ Fill factor $(\%)$

$A=$ luas permukaan modul surya $\left(\mathrm{m}^{2}\right)$

\section{HASIL DAN PEMBAHASAN}

Efisiensi merupakan perbandingan dari suatu energi listrik yang dihasilkan oleh panel surya serta irradiasi ataupun jumlah energi yang diperoleh terpapar langsung pada luas permukaaan panel. Saat cuaca cerah nilai irradiasi bisa mencapai $1000 \mathrm{~W} / \mathrm{m}^{2}$, yang berarti bahwa apabila suatu panel mempunyai luasan $1 \mathrm{~m}^{2}$ serta efisiensi yang didapat adalah sebesar $10 \%$ maka daya yang dihasilkan sebesar $100 \mathrm{~W}$. suatu panel surya memiliki efisiensi rata - rata sebesar 8-18\%. Jenis panel berbeda akan memiliki efisiensi yang juga berbeda tergantung dari bahan dasar pembuatannya.

Adapun sampel data yang diambil yaitu pada tanggal 22 juni 2021 ditunjukan seperti pada tabel 1.

Tabel 1. Data Penelitian tanggal 22 Juni 2021

\begin{tabular}{|c|c|c|c|c|c|c|c|c|}
\hline \multirow{2}{*}{ No } & \multirow{2}{*}{ Waktu } & \multicolumn{3}{|c|}{$\begin{array}{c}\text { Data Output } \\
\text { Monokristaline }\end{array}$} & \multicolumn{3}{c|}{ Data Output } & \multirow{2}{*}{$\begin{array}{c}\text { Angin } \\
\text { (m/s) }\end{array}$} \\
\cline { 3 - 9 } & & $\begin{array}{c}\text { Tegangan } \\
\text { (V) }\end{array}$ & $\begin{array}{c}\text { Arus } \\
\text { (A) }\end{array}$ & $\begin{array}{c}\mathbf{P} \\
\text { (watt) }\end{array}$ & $\begin{array}{c}\text { Tegangan } \\
\text { (V) }\end{array}$ & $\begin{array}{c}\text { Arus } \\
\text { (A) }\end{array}$ & $\begin{array}{c}\mathbf{P} \\
\text { (watt) }\end{array}$ & \\
\hline 1 & 09.00 & 20,3 & 0,72 & 14,616 & 20,5 & 0,44 & 9,02 & 0,5 \\
\hline 2 & 09.30 & 20,2 & 0,31 & 6,262 & 20,3 & 0,2 & 4,06 & 2 \\
\hline 3 & 10.00 & 20,1 & 0,28 & 5,628 & 20,3 & 0,45 & 9,135 & 0,3 \\
\hline 4 & 10.30 & 20,1 & 0,23 & 4,623 & 20,2 & 0,25 & 5,05 & 0,2 \\
\hline 5 & 11.00 & 20,2 & 0,26 & 5,252 & 20 & 0,26 & 5,2 & 0,8 \\
\hline 6 & 11.30 & 20,3 & 0,22 & 4,466 & 20 & 0,19 & 3,8 & 1,4 \\
\hline 7 & 12.00 & 20,3 & 0,31 & 6,293 & 20,4 & 0,28 & 5,712 & 1,7 \\
\hline 8 & 12.30 & 20,3 & 0,21 & 4,263 & 20 & 0,2 & 4 & 2,5 \\
\hline 9 & 13.00 & 19,8 & 0,17 & 3,366 & 18,5 & 0,21 & 3,885 & 1 \\
\hline 10 & 13.30 & 19,7 & 0,18 & 3,546 & 18,3 & 0,19 & 3,477 & 2,4 \\
\hline 11 & 14.00 & 19,5 & 0,18 & 3,51 & 18,1 & 0,18 & 3,258 & 2,5 \\
\hline \multicolumn{2}{|c|}{ Rata-rata } & $\mathbf{2 0 , 0 7 2}$ & $\mathbf{0 , 2 7 9}$ & $\mathbf{5 , 6 2 0}$ & $\mathbf{1 9 , 6 9 0}$ & $\mathbf{0 , 2 5 9}$ & $\mathbf{5 , 1 4 5}$ & $\mathbf{1 , 3 9 0}$ \\
\hline
\end{tabular}




\begin{tabular}{|c|c|c|c|c|c|c|}
\hline \multirow{2}{*}{ Waktu } & \multicolumn{2}{|c|}{$\begin{array}{c}\text { Suhu Panel } \\
\text { Surya }\end{array}$} & \multicolumn{2}{|c|}{ Pengaruh Lingkungan } & \multirow{2}{*}{ Ket } \\
\cline { 2 - 6 } & $\begin{array}{c}\text { Mono } \\
\left({ }^{\circ} \mathbf{C}\right)\end{array}$ & $\begin{array}{c}\text { Poli } \\
\left({ }^{\circ} \mathbf{C}\right)\end{array}$ & $\begin{array}{c}\text { Intensitas } \\
\text { Matahari (w/m2) }\end{array}$ & $\begin{array}{c}\text { suhu } \\
\text { ambient }\end{array}$ & $\begin{array}{c}\text { kelembaman } \\
(\%)\end{array}$ & \\
\hline 09.00 & 50,6 & 50,7 & 826,5 & 30 & 71,7 & CERAH \\
\hline 09.30 & 49,3 & 50,3 & 656,8 & 30 & 67,5 & CERAH \\
\hline 10.00 & 50,1 & 50,2 & 873,5 & 31 & 67,6 & CERAH \\
\hline 10.30 & 51,3 & 49,5 & 743 & 32 & 66,6 & CERAH \\
\hline 11.00 & 44,8 & 44,9 & 706,9 & 31,6 & 66 & CERAH \\
\hline 11.30 & 47,2 & 47,7 & 691 & 32,2 & 64 & CERAH \\
\hline 12.00 & 52 & 52,2 & 708,2 & 31,6 & 65,4 & CERAH \\
\hline 12.30 & 45,3 & 45,4 & 546,5 & 30,3 & 68,5 & CERAH \\
\hline 13.00 & 31,7 & 31,1 & 181,8 & 30,9 & 68 & MENDUNG \\
\hline 13.30 & 31,5 & 31,3 & 180,5 & 31 & 67 & MENDUNG \\
\hline 14.00 & 31 & 30 & 180,2 & 31,6 & 67 & MENDUNG \\
\hline & $\mathbf{4 4 , 0 7 2}$ & $\mathbf{4 3 , 9 3 6}$ & $\mathbf{5 7 2 , 2 6 3}$ & $\mathbf{3 1 , 1 0 9}$ & $\mathbf{6 7 , 2 0 9}$ & \\
\hline
\end{tabular}

Berdasarkan data yang didapat pada Tabel 1 yang merupakan tabel hasil pengukuran yang dilakukan pada tanggal 22 juni 2021. Tabel diatas merupakan hasil pengukuran jenis panel surya monokristalin dan polikristalin yang terdiri dari nilai arus, tegangan, daya, suhu panel, suhu lingkungan, intensitas matahari, kecepatan angin serta kelembaban. Dari tabel penelitian diatas, untuk bisa mengetahui suatu daya keluaran panel, maka dapat dihitung berdasarkan pada persamaan 2 .

Pin $=$ Ir $\operatorname{rata2} \times \mathrm{A} \quad$, didapatkan perhitungan sebagai berikut

$$
\begin{aligned}
>\text { Pin (monokristalin) } & =572,26 \mathrm{~W} / \mathrm{m}^{2} \times 0,06289 \mathrm{~m}^{2} \\
& =35,98 \mathrm{watt} \\
>\text { Pin (polikristalin) } & =572,26 \mathrm{~W} / \mathrm{m}^{2} \times 0,067 \mathrm{~m}^{2} \\
& =38,34 \mathrm{watt}
\end{aligned}
$$

Adapun untuk menghitung faktor pengisian / fill factor, yang merupakan salah satu besaran yang menjadi parameter unjuk kerja sel surya, fill faktor ini merupakan salah satu besaran tak berdimensi yang menyatakan antara perbandingan daya maksimum yang dihasilkan sel surya terhadap perkalian antara Voc dan Isc.

yaitu maka dapat dihitung berdasarkan pada persamaan 3

$$
\mathrm{FF}=\frac{V p m \times I p m}{V o c \times I s c}
$$

Perlu diketahui bahwa parameter fill factor diatas diperoleh dari nameplate masingmasing panel surya.

$$
\begin{gathered}
>\mathrm{FF} \text { (monokristalin) } \quad=\frac{18,1 \mathrm{~V} \times 5,54 \mathrm{~V}}{22,2 \mathrm{~A} \times 6 \mathrm{~A}} \\
=0,753 \\
>\mathrm{FF} \text { (polikristalin) } \quad=\frac{17,6 \mathrm{~V} \times 5,70 \mathrm{~A}}{22 \mathrm{Vx} 6,06 \mathrm{~A}} \\
=0,752
\end{gathered}
$$

Untuk menghitung Daya Outputnya, dapat dihitung dengan menggunakan persamaan 2.4 yaitu:

$$
\text { Pout }=\text { Vrata }- \text { ratax Irata }- \text { rata } x F
$$




$$
\begin{aligned}
\mathrm{P} \text { out }(\text { monokristalin) } & =20,072 \mathrm{~V} \times 0,279 \mathrm{~A} \times 0,753 \\
& =4,216 \mathrm{watt} \\
\mathrm{P} \text { out (polikristalin) } & =19,690 \mathrm{~V} \times 0,259 \mathrm{~A} \times 0,752 \\
& =3,834 \mathrm{watt}
\end{aligned}
$$

Untuk menghitung nilai Daya Maksimumnya, maka dapat dihitung dengan menggunakan persamaan 5 yaitu:

Pin $=$ Ir maks $x$ A

$$
\begin{array}{ll}
>\text { Pin (monokristalin) } & =873,5 \times 0,06298=55,013 \text { watt } \\
>\text { Pin (polikristalin) } & =873,5 \times 0,067=58,524 \text { watt }
\end{array}
$$

$\mathrm{FF}=\frac{V p m \times I p m}{\operatorname{Voc} \times I s c}$

$$
\begin{aligned}
>\mathrm{FF}(\text { monokristalin }) & =\frac{18,1 \mathrm{~V} \times 5,54 \mathrm{~V}}{22,2 \mathrm{~A} \times 6 \mathrm{~A}} \\
& =0,753 \\
>\mathrm{FF}(\text { polikristalin }) & =\frac{17,6 \mathrm{~V} \times 5,70 \mathrm{~A}}{22 \mathrm{~V} \times 6,06 \mathrm{~A}} \\
& =0,752
\end{aligned}
$$

Pout $=$ Vmaks $\mathrm{x}$ Imaks $\times \mathrm{FF}$

$>$ Pout (monokristalin) $=20,1 \times 0,28 \times 0,753=4,237$ watt

$>$ Pout (polikristalin) $\quad=20,3 \times 0,45 \times 0,752=6,869$ watt

Hasil perhitungan daya keluaran pada panel surya diatas, bisa digunakan untuk menghitung seberapa besar tingkat efisiensi suatu panel surya. Sehingga bisa dihitung nilai efisiensi yaitu dengan menggunakan persamaan 6 .

$$
\begin{aligned}
& \eta=\frac{V x I \times F F}{\operatorname{Ir} x A} \times 100 \% \\
& >\mathrm{n}(\text { monokristalin })=\frac{20,072 \times 0,279 \times 0,753}{572,26 \times 0,06289} \times 100 \% \\
& =11,716 \% \\
& >\mathrm{n}(\text { polikristalin })=\frac{19,690 \times 0,279 \times 0,752}{572,26 \times 0,067} \times 100 \% \\
& =10,002 \%
\end{aligned}
$$

Didapatkan hasil bahwa pada panel monokristalin menghasilkan efisiensi sebesar $11,716 \%$ sedangkan pada panel polikristalin menghasilkan efisiensi sebesar $10,002 \%$. Untuk perhitungan di hari penelitian lain, bisa dihitung dengan metode yang sama seperti pada perhitungan diatas. Adapun hasil perhitungan penelitian pada hari yang lain dapat ditunjukan pada tabel 2.

Tabel 2. Hasil Perhitungan Penelitian Pada Hari Lain

\begin{tabular}{|c|c|c|c|c|}
\hline \multirow{2}{*}{ Sample } & \multicolumn{2}{|c|}{ Daya Input } & \multicolumn{2}{c|}{ Daya Output } \\
\cline { 2 - 5 } & Monokristalin & Polikristalin & Monokristalin & Polikristalin \\
\hline 16 Juni 2021 & 8,731 watt & 8,918 watt & 4,823 watt & 4,409 watt \\
\hline 29 Juni 2021 & 29,838 watt & 31,788 watt & 3,755 watt & 3,290 watt \\
\hline 30 Juni 2021 & 9,540 watt & 10,163 watt & 3,367 watt & 3,209 watt \\
\hline 01 Juli 2021 & 15,071 watt & 16,056 watt & 3,299 watt & 2,799 watt \\
\hline 02 Juli 2021 & 55,534 watt & 59,164 watt & 5,588 watt & 7,097 watt \\
\hline
\end{tabular}


Dari data diatas, dapat disimpulkan bahwa perbedaan nilai daya antara panel monokristalin dan polikristalin tersebut disebabkan oleh faktor kondisi cuacanya, semakin cerah cuaca maka nilai dayanya pun akan naik begitupun sebaliknya saat kondisi cuaca mendung nilai dayanya pun akan cenderung menurun.

Dari perhitungan diatas, Adapun rangkuman hasil efisiensi dari penelitian yang telah dilakukan, yaitu seperti ditunjukan pada tabel 3 .

Tabel 3. Perbandingan efisiensi panel polikristalin dan monokristalin.

\begin{tabular}{|c|c|c|}
\hline \multirow{2}{*}{ Sample } & \multicolumn{2}{|c|}{ Efisiensi } \\
\cline { 2 - 3 } & Monokristalin & Polikristalin \\
\hline 16 Juni 2021 & $57,61 \%$ & $45,40 \%$ \\
\hline 22 Juni 2021 & $11,716 \%$ & $10,002 \%$ \\
\hline 29 Juni 2021 & $12,58 \%$ & $10,34 \%$ \\
\hline 30 Juni 2021 & $35,29 \%$ & $31,57 \%$ \\
\hline 01 Juli 2021 & $21,88 \%$ & $17,43 \%$ \\
\hline 02 Juli 2021 & $10,06 \%$ & $11,99 \%$ \\
\hline Rata rata & $24,35667 \%$ & $21,12167 \%$ \\
\hline
\end{tabular}

Berdasarkan pada tabel 3 efisiensi panel jenis monokristalin secara keseluruhan lebih baik dibandingkan dengan panel polikristalin, meskipun di tanggal 2 juli efisiensi lebih besar pada panel polikristalin. Hal tersebut dikarenakan kondisi saat itu cuaca berubah ubah pada saat pengambilan data.

\subsection{Analisa Pengaruh Suhu dan Kecepatan Angin}

Untuk mengetahui seberapa besar pengaruh kecepatan angin pada efisisensi panel surya, bisa dihitung dengan menggunakan metode regresi linear pada Microsoft excel.

Adapun hasil yang diperoleh berdasarkan pengukuran secara langsung adalah seperti pada gambar 1.

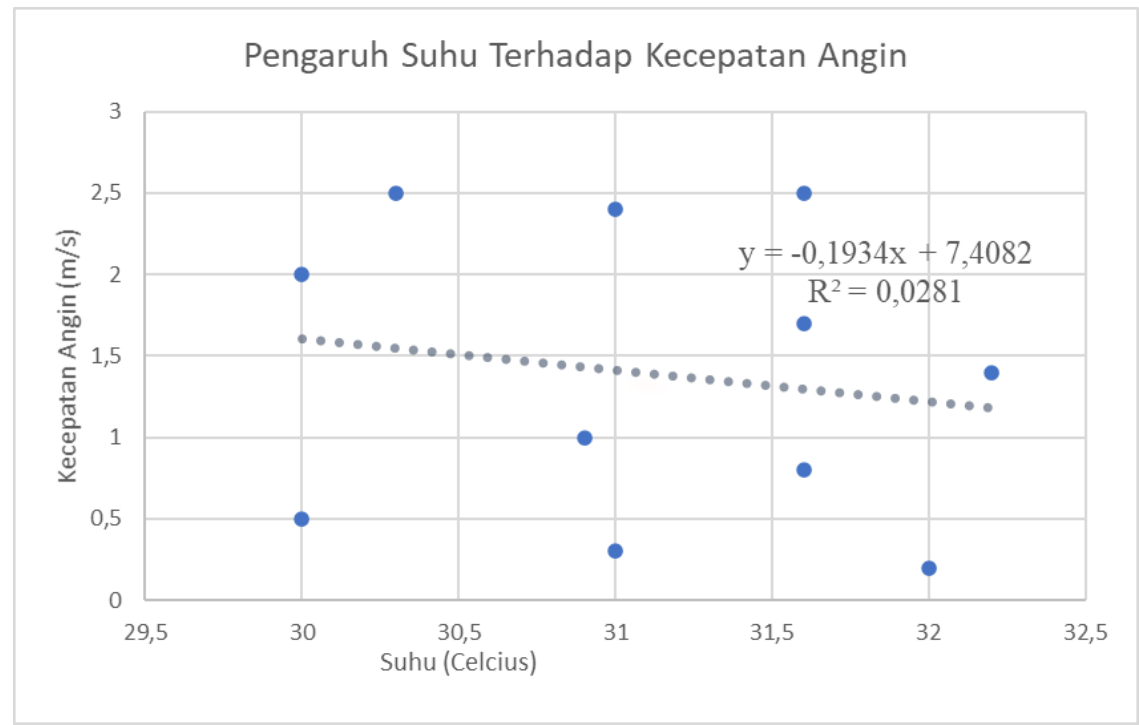

Gambar 1. Grafik Pengaruh Suhu dan Kecepatan Angin 
Dari perhitungan yang telah dilakukan, diperoleh hasil bahwa pengaruh suhu dan kecepatan angin pada efsisiensi panel surya menggunakan persamaan regresi linear menunjukkan tingkat korelasi $R=0,0281$ yang berarti bahwa hanya sekitar $2,81 \%$ kecepatan angin yang berpengaruh pada efisiensi panel surya dan sekitar $97,19 \%$ sisanya dipengaruhi oleh faktor lain seperti intensitas cahaya matahari, sudut kemiringan, dan lainnya. Dimana nilai koefisien yang ditunjukan antara -1 sampai 1 . Nilai -1 berarti korelasinya sangat kuat namun berbanding terbalik, sedangkan nilai koefisien 1 maka korelasinya sangat kuat dan serta berbanding lurus, dan nilai koefisien 0 berarti menunjukkan bahwa korelasi antar variabel sangat rendah. korelasi kecepatan angin pada efisiensi panel surya rendah yaitu hanya sekitar $2,81 \%$.

\section{KESIMPULAN DAN SARAN}

Berdasarkan hasil penelitian yang telah dilakukan, maka dapat disimpulkan bahwa dari berbagai aspek perhitungan yang telah dilakukan diperoleh bahwa efisiensi panel jenis monokristalin lebih baik daripada panel jenis polikristalin. Berdasarkan pada nilai efisiensinya, panel yang cocok dikembangkan adalah jenis panel monokristalin dengan perbandingan rata rata panel jenis monokristalin sebesar $24,35 \%$ sedangkan panel polikristalin sebesar $21,12 \%$. Pengaruh kecepatan angin pada efisiensi panel surya yang telah dihitung berdasakan perhitungan dengan metode regresi linear menunjukkan tingkat korelasi $R=0,0281$ yang berarti bahwa hanya sekitar 2,81\% kecepatan angin yang berpengaruh pada efisiensi panel surya.

Adapun saran penulis untuk penelitian lebih lanjut yaitu untuk bisa mendapatkan hasil yang lebih akurat, alangkah baiknya jika menggunakan sistem monitoring panel surya seperti data logger dengan Arduino uno. Serta perlu juga untuk digunakan parameter yang lebih banyak selain suhu dan kecepatan angin seperti efek shading ataupun yang lainnya untuk mengetahui faktor lain yang berpengaruh pada efisiensi panel surya.

\section{DAFTAR PUSTAKA}

[1] Andi Makkulau, Samsurizal, S., \& Fikri, M. (2019). Pengaruh Intensitas Matahari Terhadap Karakteristik Sel Surya Jenis Polycristaline Menggunakan Regresi Linear. KILAT, 69-76.

[2] Aprilia, B. S., Zulfahmi, M. R., \& Rizal, A. (2019). Investigasi Efek Partial Shading Terhadap Daya Keluaran Sel Surya. ELEMENTER.

[3] Ar-rasyid, M. N. (2019). Analisis Pengaruh Koefisien Temperatur Terhadap Daya Keluaran Panel Surya. JAKARTA: STT-PLN.

[4] Asrori, \& Yudianto, E. (2019). Kajian Karakteristik Temperatur Permukaan Panel terhadap Performansi Instalasi Panel Surya Tipe Mono dan Polikrista. JURNAL TEKNIK MESIN UNTIRTA, 68-73.

[5] Cahyono, G. R., Ansyah, P. R., \& Munthaha, M. (2020). Pengaruh Variasi Kecepatan Hembusan Udara Terhadap Temperatur Daya Output dan Efisiensi Pada Pendinginan Panel Surya. Infotekmesin, 141-146.

[6] Kayani, U. A. (2019). Effect of temperature and wind on PV Module's efficiency (Energy and Resource Utilization).

[7] Khwee, K. H. (2013). Pengaruh Temperatur Terhadap Kapasitas Daya Panel Surya (Studi Kasus Pontianak). ELKHA. 
[8] Napitupulu, R. (2017). Pengaruh material monokristal dan polikristal terhadap karakteristik panel surya 20 wp. Poliprofesi.

[9] Pagan, S. P., \& Sara, I. D. (2018). Komparasi Kinerja Panel Jenis Monokristal dan Polykristal Studi Kasus Cuaca Banda Aceh . KITEKTRO, 19-23.

[10] Pradana, I. S. (2018). Sistem Sensor Kecepatan Angin Menggunakan Anemometer Model JL-FS2 Berbasis Mikrokontroller Atmega328 Untuk Melihat Pengaruh Kecepatan Angin Terhadap Efisiensi Panel Surya. Medan: Universitas Sumatera Utara.

[11] PS, W., Faizal, A., Widianto, E., \& Iman, A. (2018). Analisis Computation Fluid Dynamics Suhu Permukaan Panel Surya Akibat Pengaruh Intensitas Radiasi Matahari, Kecepatan Angin dan Suhu Udara. Jurnal IImiah Teknik Mesin.

[12] Tira, H., Natsir, A., \& Putranto, T. (2020). Kinerja modul surya melalui variasi solar collector dan kecepatan angin. Dinamika Teknik Mesin, 25-32.

[13] Makkulau, A. Christiono and Samsurizal," Characteristics of Temperature Changes Measurement on Photovoltaic Surfaces Against Quality of Output Current on Solar Power Plants,". In International Conference on Technologies and Policies in Electric Power \& Energy, IEEE, vol. doi (Vol. 10, pp. 1-4).

[14] Samsurizal, S., Christiono, C., \& Husada, H. (2020). Studi Kelayakan Pemanfaatan Energi Matahari Sebagai Pembangkit Listrik Tenaga Surya Di Dusun Toalang. Setrum: Sistem Kendali-Tenaga-elektronika-telekomunikasi-komputer, 9(1), 75-83.

[15] Makkulau, A., Samsurizal, S., \& Fikri, M. (2021). Pengaruh Intensitas Matahari Terhadap Karakteristik Sel Surya Jenis Polycristaline Menggunakan Regresi Linear. KILAT, 10(1), 69-76.

[16] Samsurizal, Kartika Tresya, Miftahul Fikri, Nurmiati Pasra, Christiono. (2021). Pengenalan Pembangkit Listrik Tenaga Surya (PLTS). Institut Teknologi PLN. Jakarta 